\title{
The effects of force-feeding on enzymes of the liver, kidney, pancreas and digestive tract of chicks
}

\author{
BY ZAFRIRA NITSAN* \\ Division of Poultry Science, Agricultural Research Organization, \\ The Volcani Center, Rehovot, Israel \\ AND Y. DROR \\ Department of Agricultural Biochemistry, Faculty of Agriculture, \\ Hebrew University of Ferusalem, Rehovot, Israel \\ AND I. NIR AND NIVA SHAPIRA \\ Department of Animal Hygiene and Poultry Science, \\ Faculty of Agriculture, Hebrew University of Ferusalem, Rehovot, Israel
}

(Received 2 August 1973-Accepted 24 October 1973)

\footnotetext{
I. Force-feeding of young chicks for $\mathrm{I}_{5} \mathrm{~d}$ increased kidney arginase $(E C 3 \cdot 5 \cdot 3 \cdot \mathrm{r})$ activity threefold. Fasting for $30 \mathrm{~h}$ decreased this activity by $50 \%$.

2. Liver xanthine dehydrogenase was slightly increased after force-feeding and decreased following fasting.

3. The specific activities of two pentose-phosphate-cycle enzymes were not significantly affected by force-feeding, but glucose-6-phosphate dehydrogenase (EC I , I . I . 49) decreased following fasting.

4. The over-all secretion of digestive enzymes increased parallel to the increase in food consumption. Therefore, despite an increased absolute weight of the pancreas and intestinal chyme, specific activities were the same in the force-fed and ad lib.-fed groups, except for a higher activity in intestinal amylase.

5. Fasting did not affect the pancreatic enzymic activities.
}

Force-feeding of young chicks increases growth rate (by $60 \%$ ) and energy utilization. The increase in body-weight is due mainly to lean body-weight and partly to fat (Nir, Shapira, Nitsan \& Dror, 1974). Force-feeding geese with maize is associated with an increase in the activities of liver xanthine dehydrogenase (XDH), kidney arginase $(E C \quad 3 \cdot 5 \cdot 3.1)$ and glucose-6-phosphate dehydrogenase (G6PD) (EC I.I.I.49) per g tissue and with a decrease in 6-phosphogluconic dehydrogenase (6PGD) (EC I.I.I.43). The specific activities of digestive enzymes are reduced in the pancreas and intestinal tract (Nitsan, Nir, Dror \& Bruckental, 1973), but the total amount of enzyme in the excreta is increased for the proteolytic enzymes and decreased for amylase ( $\mathrm{Nir}$, Nitsan \& Vax, 1973). The activities of most of the enzymes, especially that of the amylase, are increased after supplementing the maize with soya-bean meal.

In the present study the enzymic adaptability of young chicks in digesting and metabolizing excessive amounts of nutrients was investigated. For this purpose we studied the effect of force-feeding and subsequent fasting on the activities of enzymes

* Contribution No. 243-E, 1973 series. 
involved in protein catabolism in liver and kidneys, enzymes of the pentose phosphate cycle in liver and enzymes in pancreas and digestive tract.

\section{EXPERIMENTAL}

The chicks were cross-bred male New Hampshire $\times$ White Leghorn. Care of the chicks, diets, technique of force-feeding and of autopsy are described elsewhere (Nir et al. I974). The birds were killed at $29 \mathrm{~d}$ of age. After autopsy, the livers were quickly rinsed with saline ( $9 \mathrm{~g}$ sodium chloride/1), blotted on filter paper, weighed and frozen at $-22^{\circ}$. The kidney, pancreas, intestinal and caecal contents were weighed and frozen $\left(-22^{\circ}\right)$ for enzymic determinations.

\section{Determination of enzyme activities}

Renal arginase activity was determined as described by Dror \& Gertler (1967) except that $4 \mathrm{~mm}-\mathrm{MnSO}_{4}$ was added to the medium. $\mathrm{XDH}$ activity in liver was determined according to Strittmatter $\left(\mathrm{I}_{9} 6_{5}\right)$. The assay was performed with a model 2400 Gilford spectrophotometer (Gilford Instruments Ltd, Morden, Surrey). The extinction of each sample was measured for 2 min against its blank, in which xanthine was omitted. 6PGD and G6PD of liver were determined as described by Dror, Sassoon, Watson \& Johnson (I970).

The pancreas was homogenized in ro vol. cold distilled-water and centrifuged at $70000 \mathrm{~g}$ for $20 \mathrm{~min}$. Lipase (EC 3.I.I.3) was determined in the homogenate by a modified procedure of Sarda \& Desnuelle (1958); amylase by the method of Bernfeld (1955), with modification as described by Gertler \& Nitsan (1970). Trypsin (EC $3.4 .4 .4)$ and chymotrypsin $A(E C 3.4 .4 .5)$ were determined after activation of the pancreatic homogenate according to Gertler \& Nitsan (1970). N-benzoyl-DL-arginine$p$-nitroanilide-HCl (BANA) and $\mathrm{N}$-acetyl-L-tyrosine- $p$-nitroanilide (ATNA) (E. Merck, Darmstadt, W. Germany), were used as substrates for trypsin and chymotrypsin, the final concentration being $\mathrm{I} \cdot 25 \mathrm{mM}$ in $3.7 \mathrm{~mm}$-Tris buffer, $\mathrm{pH} 7.8,0.6 \mathrm{mM}^{-\mathrm{CaCl}_{2}}$ and $25 \mathrm{mg} / \mathrm{ml}$ dimethylformamide. The reaction proceeded at $30^{\circ}$ for $30 \mathrm{~min}$ and was stopped with acetic acid $(300 \mathrm{ml} / \mathrm{l})$. The colour developed was measured at 4IO $\mathrm{nm}$. The enzyme concentration was calculated using standard curves which were prepared with pure enzyme preparations (Sigma, St Louis, Missouri, USA) by the same procedure. Activity units were calculated as follows: for $\mathrm{XDH}, 6 \mathrm{PGD}$ and G6PD, $\mu \mathrm{mol} \mathrm{NAD}$ or NADP reduced $/ \mathrm{min}$ at $30^{\circ}$; for arginase and lipase, $\mu \mathrm{mol}$ product formed $/ \mathrm{min}$ at $30^{\circ}$; for amylase, extinction at $550 \mathrm{~nm}\left(\times 10^{-2}\right) / 3 \mathrm{~min}$, using $12.7 \mathrm{~mm}$ Bausch \& Lomb test-tubes, at $37^{\circ}$.

Statistical analysis was done by the method of Snedecor \& Cochran (1967) as detailed by Nir et al. (1974).

\section{RESULTS}

Activity of kidney arginase was markedly increased after force-feeding; the increase was threefold when expressed as units/g or about fivefold when expressed as units/ kidney (Table I). The activity was reduced by approximately $50 \%$ after fasting for 
Table I. Enzyme activities in the liver and kidney of chicks fed ad lib. or force-fed, before and after fasting

(Mean values for eight chicks/group)

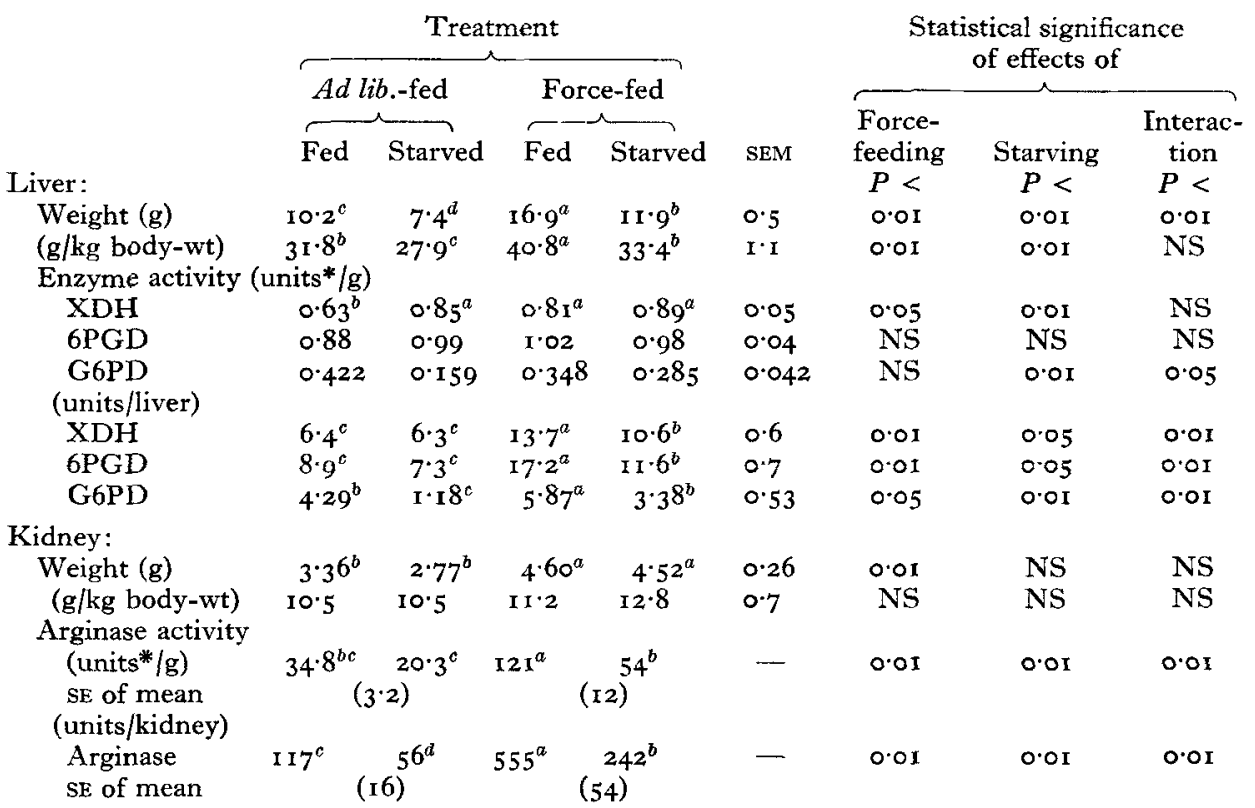

NS, non-significant; XDH, xanthine dehydrogenase; 6PGD, 6-phosphogluconic dehydrogenase; G6PD, glucose-6-phosphate dehydrogenase.

Values followed by a common superscript do not differ significantly $(P<0.05)$.

* See p. 242.

about $3 \circ \mathrm{h}$, and was reduced more in the force-fed group. This difference was highly significant $(P<0 \cdot 01)$. The specific activity of liver $\mathrm{XDH}$ was increased by either force-feeding or fasting. Specific activities of liver 6PGD and G6PD were not affected by force-feeding, but the G6PD activity was reduced following fasting (Table $\mathrm{r})$. This effect was greater $(P<0.05)$ for the ad lib. group. Total activities of the liver enzymes increased concomitantly with the increase in liver weight of the force-fed chicks.

Pancreatic lipase, amylase, chymotrypsin and XDH total activities were significantly increased in the force-fed groups; lipase and XDH activities decreased after fasting. Trypsin activity was not affected significantly by either force-feeding or fasting (Table 2). Amylase activity (units/g) was increased in the small intestine contents of the force-fed group. No changes were observed in the activities of other enzymes in the small intestine when expressed as units/g. The total activities of these enzymes in the small intestine as units/g total chyme were increased in the forcefed group in parallel with the increase in the amount of the chyme, without a diluting effect. The small intestine content of the force-fed group was $63 \%$ higher than that of the ad lib. group and $25 \%$ higher when calculated as $\mathrm{g} / \mathrm{kg}$ body-weight.

A general trend toward decrease was found in the enzyme activities of the caecum 
Table 2. Enzyme activities in the pancreas of chicks fed ad lib., or force-fed, before and after starving

(Mean values for eight chicks/group)

\begin{tabular}{|c|c|c|c|c|c|c|c|c|}
\hline \multirow[b]{3}{*}{ Pancreas: } & \multicolumn{4}{|c|}{ Treatment } & \multirow{3}{*}{$\begin{array}{l}\text { SE of } \\
\text { mean }\end{array}$} & \multicolumn{3}{|c|}{$\begin{array}{l}\text { Statistical significance } \\
\text { of effects of }\end{array}$} \\
\hline & \multicolumn{2}{|c|}{ Ad lib.-fed } & \multicolumn{2}{|c|}{ Force-fed } & & \multirow{2}{*}{$\begin{array}{l}\text { Force- } \\
\text { feeding } \\
P<\end{array}$} & \multirow[b]{2}{*}{$\begin{array}{l}\text { Starving } \\
P<\end{array}$} & \multirow{2}{*}{$\begin{array}{c}\text { Interac- } \\
\text { tion }\end{array}$} \\
\hline & Fed & Starved & Fed & Starved & & & & \\
\hline Weight (g) & $I \cdot 4 I^{b}$ & $\mathbf{I} \cdot 09^{c}$ & $\mathbf{I} \cdot 89^{a}$ & $\mathrm{I} \cdot 64^{a b}$ & 0.10 & 0.01 & 0.05 & NS \\
\hline (g/kg body-wt) & $4 \cdot 4$ & $4 \cdot 1$ & $4 \cdot 5$ & $4 \cdot 6$ & 0.3 & NS & NS & NS \\
\hline \multicolumn{9}{|c|}{ Enzyme activity (units*/g) } \\
\hline Lipase & $94^{a}$ & $66^{b}$ & $\log ^{a}$ & $9 \mathbf{r}^{a}$ & 8 & 0.05 & 0.05 & NS \\
\hline Amylase & 94 & 105 & IO3 & 107 & 9 & NS & NS & NS \\
\hline Trypsin & $17 \cdot 7$ & $18 \cdot 6$ & $15 \cdot 4$ & 16.6 & $I \cdot 6$ & NS & NS & NS \\
\hline Chymotrypsin & 84 & 82 & 97 & 99 & II & NS & NS & NS \\
\hline $\mathrm{XDH}$ & 0.237 & 0.215 & 0.289 & 0.228 & 0.045 & NS & NS & NS \\
\hline \multicolumn{9}{|c|}{ (units*/pancreas) } \\
\hline Lipase & $132^{b}$ & $71^{c}$ & $193^{a}$ & $149^{b}$ & 15 & 0.01 & 0.01 & NS \\
\hline Amylase & $132^{b}$ & $\mathrm{I} I 4^{b}$ & $195^{a}$ & $175^{a}$ & 16 & 0.01 & NS & NS \\
\hline Trypsin & 24.9 & 20.2 & $29 \cdot 1$ & $27 \cdot 2$ & $I \cdot 9$ & NS & NS & NS \\
\hline Chymotrypsin & $1 \pm 8^{b}$ & $89^{b}$ & $183^{a}$ & $162^{a}$ & 16 & 0.01 & 0.05 & NS \\
\hline $\mathrm{XDH}$ & $0.334^{b}$ & $0.234^{c}$ & $0.546^{a}$ & $0.374^{b}$ & 0.052 & 0.01 & 0.05 & NS \\
\hline
\end{tabular}

$\mathrm{NS}$, non-significant; $\mathrm{XDH}$, xanthine dehydrogenase.

Values followed by a common superscript do not differ significantly $(P<0.05)$.

* See p. 242 .

\section{Table 3. Enzyme activities in the small intestine and caecum of chicks fed ad lib. or force-fed}

(Mean values for eight chicks/group)

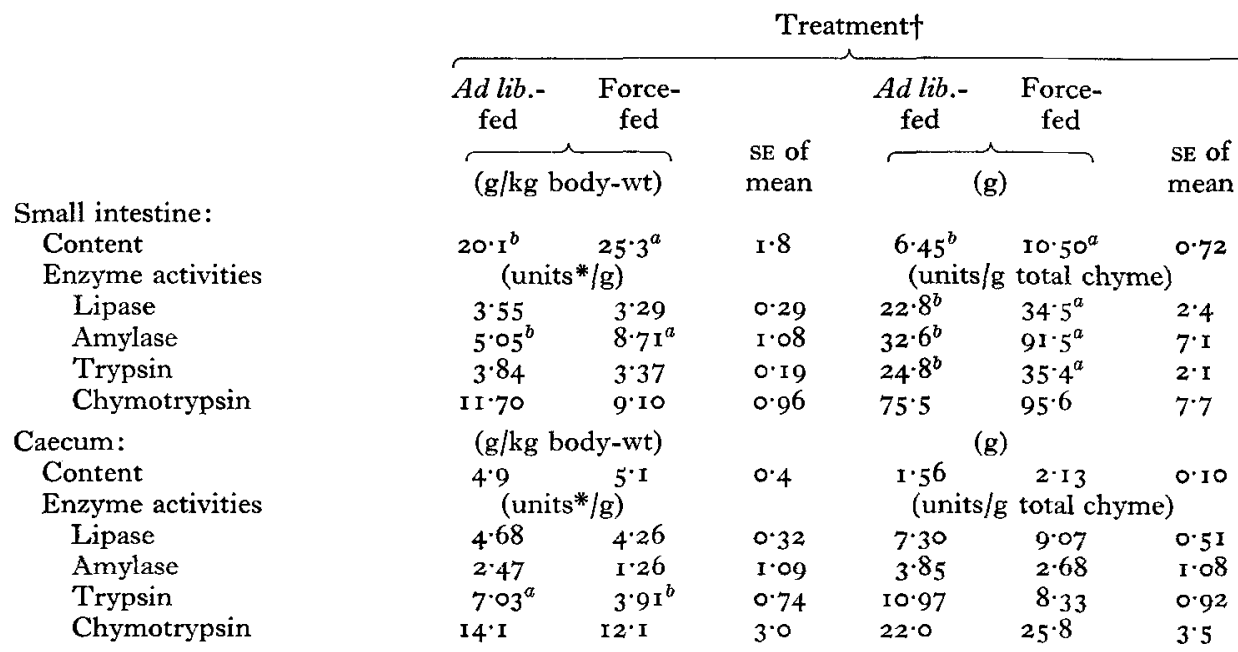

Values followed by a common superscript do not differ significantly $(P<0.05)$.

* See p. 242 .

$\uparrow$ No intestinal content was found in the fasted birds. 
contents when expressed as units/g. Only the reduction of trypsin activity was statistically significant $(P<0.05)$. Similar activities were observed in the total amount of the caecal chyme of both groups ('Table 3 ).

\section{DISCUSSION}

Kidney arginase activity. The specific activity of kidney arginase was increased threefold in the force-fed groups compared with that of the ad lib.-fed groups. This increase was much higher than the $50 \%$ increase in body-weight gain, the $70 \%$ increase in protein consumption, or the $20 \%$ decrease in protein utilization. In earlier work with chicks (Dror \& Nir, 197I), a threefold increase in the activity was recorded when chicks were given a $400 \mathrm{~g}$ soya-bean protein $/ \mathrm{kg}$ diet, compared with one of $200 \mathrm{~g}$ protein. An increase of two- to threefold in arginase activity was reported by Muramatsu \& Nakagawa (I97I), when starved rats were force-fed tryptophan, while a smaller increase was found when force-feeding with other essential amino acids. The increase in arginase activity in the force-fed chicks may also be due to the creation of imbalance in some essential amino acids by force-feeding (Austic \& Nesheim, I97I).

A starvation period of about $30 \mathrm{~h}$ caused a decrease of about $50 \%$ in the arginase activity. The higher activity of the force-fed group was reduced to a greater extent than the activity of the ad lib.-fed group. According to this rate of decrease of arginase activity $(50 \%$ in $30 \mathrm{~h}$ ), the half-life of the enzyme may be estimated to be less than $24 \mathrm{~h}$. This estimate is comparable with the half-life of rat liver arginase which was found to be $24 \mathrm{~h}$ by Szepesi \& Freedland (I 969 ) in a non-steady state during which the activity decreased.

$X D H$ activity. In liver, $\mathrm{XDH}$ specific activity was increased either by force-feeding or by fasting (Table $\mathrm{I}$ ). The increase due to fasting confirms the result of Scholz \& Featherston (I 1969 ), obtained when chicks given $250 \mathrm{~g}$ protein $/ \mathrm{kg}$ diet were starved for $\mathrm{I} \mathrm{d}$. The latter increase is a result of protein catabolism during fasting. The increase was greater in the ad lib.-fed group, which contained $6 \%$ carcass fat compared with I $4 \%$ in the force-fed group, and therefore used more protein as a source of energy than did the latter group, which utilized more fat during fasting (Nir et al. 1974).

A non-significant increase in pancreatic XDH specific activity was caused by the force-feeding. The response of XDH activities in the pancreas to the nutritional treatment was smaller than that found in the liver, but a small non-significant decrease was observed during fasting. Fisher, Curtis \& Woodward ( 1967 ) showed that the pancreatic XDH activity in hatching chicks is developed only after they begin to eat and that fasting for I $\mathrm{d}$ resulted in a decrease in XDH activity of about $40 \%$. They suggested different control mechanisms for $\mathrm{XDH}$ activity in liver and pancreas. The liver XDH activity (Table I) was increased after fasting and the pancreatic XDH (Table 2) was decreased. This diversity may be due to the different control mechanism of XDH activity in liver and pancreas, as suggested by Fisher et al. (1967).

Pentose phosphate cycle enzyme activities. Specific activities of 6PGD and G6PD were only slightly affected by force-feeding but G6PD activity decreased by about $60 \%$ following starvation. The lack of response of these activities to another extreme 
nutritional treatment in chicks, such as a high-carbohydrate diet, was reported by Pearce (1972). Rats could differ from chicks in this respect. A marked increase in response to the same treatment was reported by Johnson \& Sassoon (1968) in rats. A twofold increase in 6PGD activity and a $50 \%$ decrease in G6PD activity in forcefed geese was reported by Nitsan $e t$ al. (1973). There could be some difference in the importance of pentose phosphate cycle enzymes between chicks and geese, but this could be due also to the higher fat content of the livers of the geese.

Digestive enzymes levels. In the pancreas and small intestine, the increase in the total activity of these enzymes paralleled the $70 \%$ increase in food consumption brought about by force-feeding compared with the ad lib.-fed group. The specific activities of the enzymes per $g$ tissue or chyme were therefore the same in the two groups despite the bigger pancreas and increased amount of chyme in the intestines of the force-fed group. Force-feeding of maize in an amount two- to fourfold that of the ad lib. intake described in geese (Nitsan et al. 1973), caused a reduction in proteolytic and amylase activities in the enlarged digestive tract. However, the total activities of proteases in the excreta were increased, while that of amylase decreased (Nir $e t$ al. 1973). The different results obtained with the force-fed chicks and geese may be due either to the level of force-feeding or to the quality of the force-fed diet (maize $v$. starter mash). Increased food consumption level (170\%) is accompanied by an increase in synthesis of digestive enzymes and secretion at the same rate, so that no dilution effect is seen despite the bigger pancreas and intestinal content. However, in force-fed geese (intake $200-400 \%$ of ad lib. intake), although the enzyme synthesis was somewhat increased, it did not parallel the increase in the feeding level and therefore the specific activity/g chyme was reduced.

A good-quality diet supplies all the needed precursors for enzyme synthesis and therefore the force-fed chicks could produce higher amounts of digestive enzymes depending on the level of force-feeding. Maize, however, is probably deficient in some of the essential precursors for enzyme synthesis. A marked increase in the amylase secretion was observed in force-fed geese when the maize was supplemented by soya-bean meal (Nir et al. 1973). Amylase was found to be affected more than the proteolytic enzymes by the quality of the diet and responded more to methionine supplementation of the soya-bean diet (Nitsan \& Gertler, 1972). In the present work, in which a good-quality mash was used, the amylase activity per g intestinal chyme was even greater in the force-fed than in the ad lib.-fed chicks (Table 3).

Digestibility of various nutrients is not changed by a wide range of food intake and digestive enzyme levels (Scott, Nesheim \& Young, 1969; Nir et al. 1973; Dror, Shamgar \& Budowski, unpublished results). The increased enzyme activity found in force-feeding is not necessarily needed for better digestion, but can be a result of mechanical and humoral stimulation caused by the passage of greater amounts of chyme through the digestive tract. It appears that the mechanism inducing the synthesis of enzymes of the digestive tract is not predominantly controlled by the amounts and concentrations of substrates or products in the gastrointestinal tract. 
The authors acknowledge with thanks the generous contribution of $\mathrm{Mr}$ Joseph Taylor from London, England, which enabled them to carry out this work.

\section{REFERENCES}

Austic, R. E. \& Nesheim, M. C. (197I). F. Nutr. ror, I403.

Bernfeld, P. (1955). Meth. Enzym. r, I49.

Dror, Y. \& Gertler, A. (1967). F. Nutr. 93, 40r.

Dror, Y. \& Nir, I. (197I). Nutr. Metab. 13, 75.

Dror, Y., Sassoon, H. F., Watson, J. J. \& Johnson, B. C. (1970). Clinica chim. Acta 28, 291.

Fisher, J. R., Curtis, J. L. \& Woodward, W. D. (1967). Devl Biol. 15, 289.

Gertler, A. \& Nitsan, Z. (1970). Br. F. Nutr. 24, 893.

Johnson, B. C. \& Sassoon, H. T. (1968). Proc. 7th int. Congr. Nutr. p. 496.

Muramatsu, K. \& Nakagawa, 'T. (I97 I). Agric. biol. Chem. F. 35, I 594.

Nir, I., Nitsan, Z. \& Vax, A. (1973). Annls Biol. anim. Biochim. Biophys. 13, 465.

Nir, I., Shapira, N., Nitsan, Z. \& Dror, Y. (1974). Br. F. Nutr. 32, 229.

Nitsan, Z. \& Gertler, A. (1972). Br. Y. Nutr. 27, 337.

Nitsan, Z., Nir, I., Dror, Y. \& Bruckental, I. (1973). Poult. Sci. 52, 474.

Pearce, J. (1972). Biochem. F. 130, 2 I P.

Sarda, L. \& Desnuelle, P. (1958). Biochim. biophys. Acta 3o, 513,

Scholz, R. W. \& Featherston, W. R. (I969). F. Nutr. 98, 193.

Scott, M. L., Nesheim, M. C. \& Young, R. J. (1969). Nutrition of the Chicken. Ithaca, New York: M. L. Scott and Associates.

Snedecor, G. W. \& Cochran, W. G. (1967). Statistical Methods 6th ed. Ames, Iowa: Iowa State University.

Strittmatter, C. F. (1965). J. biol. Chem. 240, 2557.

Szepesi, B. \& Freedland, R. A. (1969). Life Sci. II 8, 1067. 